\title{
H2AC17 Gene
}

National Cancer Institute

\section{Source}

National Cancer Institute. H2AC17 Gene. NCI Thesaurus. Code C162906.

This gene plays a role in histone-mediated chromatin remodeling. 